\title{
AN INTEGRATED APPROACH TO GROUNDWATER POTENTIAL MODELLING IN JOS METROPOLIS, NORTH CENTRAL NIGERIA. Dauda D. D. ${ }^{1}$, Nimlang H. N. ${ }^{2}$, Goyit M. ${ }^{3}$, Davou Y.G ${ }^{4}$ and Matini J.L ${ }^{5}$ \\ ${ }^{1}$ National Centre for Remote Sensing, Jos, Nigeria. \\ ${ }^{2}$ Department of Disaster Management and Environmental Impact, IMT Mines Ales, France. \\ ${ }^{3}$ Department of Geology, University of Jos, Jos Nigeria. \\ ${ }^{4}$ Zonal Advance Space Technology Laboratory Langtang, Nigeria. \\ ${ }^{5}$ National Centre for Remote Sensing, Jos, Nigeria. \\ *E-mail corresponding author: khoidung.kd@gmail.com
}

\begin{abstract}
Groundwater resources are unevenly distributed in the crystalline basement terrain of Nigeria. Hence, the sustainable development and management of groundwater resource in such terrain requires precise quantitative assessment based on scientific principle and modern techniques. This study deals with the integrated approach of remote sensing, GIS and Analytical Hierarchy Process (AHP) in modelling groundwater potential zones within Jos, Northcentral Nigeria. Nigeria Sat - X, ASTER GDEM, topographic and geological maps of the study area are used to generate the various themes; lineaments, geology, drainage, geomorphology, surface water body and slope. Thematic weights are assign to the various layers AHP. The groundwater potential model of the area is produce by integrating the different thematic layers using Weighted Index Overlay Analysis (WIOA) in ArcGIS. Five different potential zones namely; very high, high, moderate, low and very low are determined. The groundwater potential map reveals that some parts in the northwestern, parts of the northeastern and a portion in the extreme southwestern of the study area have very low potential. Low potential is observed in the extreme northwestern, some areas in the northeast and some southwestern parts of the study area. The north central, some northwestern and northeastern as well as southern parts generally exhibits moderate potential. The high and very high groundwater potentiality of the study area is restricted to some parts in the northwest, northeast and few places in the central and southwestern part of the study area. Borehole data obtained from 127 boreholes within the study area where used to validate the groundwater potential of the study area, from which $69.29 \%$ coincided with the groundwater potential model.
\end{abstract}

Keywords: Groundwater, Modelling, Potential, Remote Sensing and GIS.

\section{INTRODUCTION}

Groundwater is one of the most valuable natural resources. It supports human health, economic development and ecological diversity. Due to its several inherent qualities (such as consistent temperature, widespread and continuous availability, excellent natural quality, limited vulnerability, low development cost and drought reliability), it has become an important and dependable source of water supplies in all climatic regions including both urban and rural areas of developed and developing countries (Todd and Mays, 2005).

The occurrence and movement of groundwater in an area is governed by several factors such as topography, lithology, geological structure, depth of weathering, slope, land use/ land cover (LULC), and interrelationship between these factors. To understand groundwater prospects of an area, integration 
of different thematic layers is required. The occurrence of groundwater at any place on the earth is not a matter of chance but a consequence of the interaction of the climatic, geological, hydrological, physiographical and ecological factors. Groundwater exploration operation is essentially a hydrogeological and geophysical inference operation and is dependent on the correct interpretation of the hydrological indicators and evidences (Ravindran, 2012).

Satellite remote sensing provides an opportunity for better observation and more systematic analysis of various geomorphic units, landforms and lineaments due to the synoptic and multi-spectral coverage of a terrain. Hence, remotely sensed data by its wide area coverage and multispectral nature has helped in identification and mapping of most of the above factors with selective ground checks in a cost-effective manner. An integrated analysis of these factors together with the available well and ancillary data in GIS environment were helpful in identifying the potential and evaluating groundwater zones.

The study area, Jos and environs, is situated in Plateau State Northcentral Nigeria. It lies between latitudes $9^{\circ} 45^{\prime} 40.9^{\prime \prime} \mathrm{N}$ and $9^{\circ} 58^{\prime} 52.8^{\prime \prime} \mathrm{N}$ and longitudes $8^{\circ} 48^{\prime} 31.5^{\prime \prime} \mathrm{E}$ and $9^{\circ} 00^{\prime} 00^{\prime \prime} \mathrm{E}$. The study area has an estimated area of $242.39 \mathrm{~km}^{2}$, it is located in Jos North, Jos South and Jos East Local Government Areas of Plateau State (Fig 1.1). The area is accessible in different parts by major road network, secondary roads and many minor roads. Several footpaths interconnect neighborhoods within the township. 


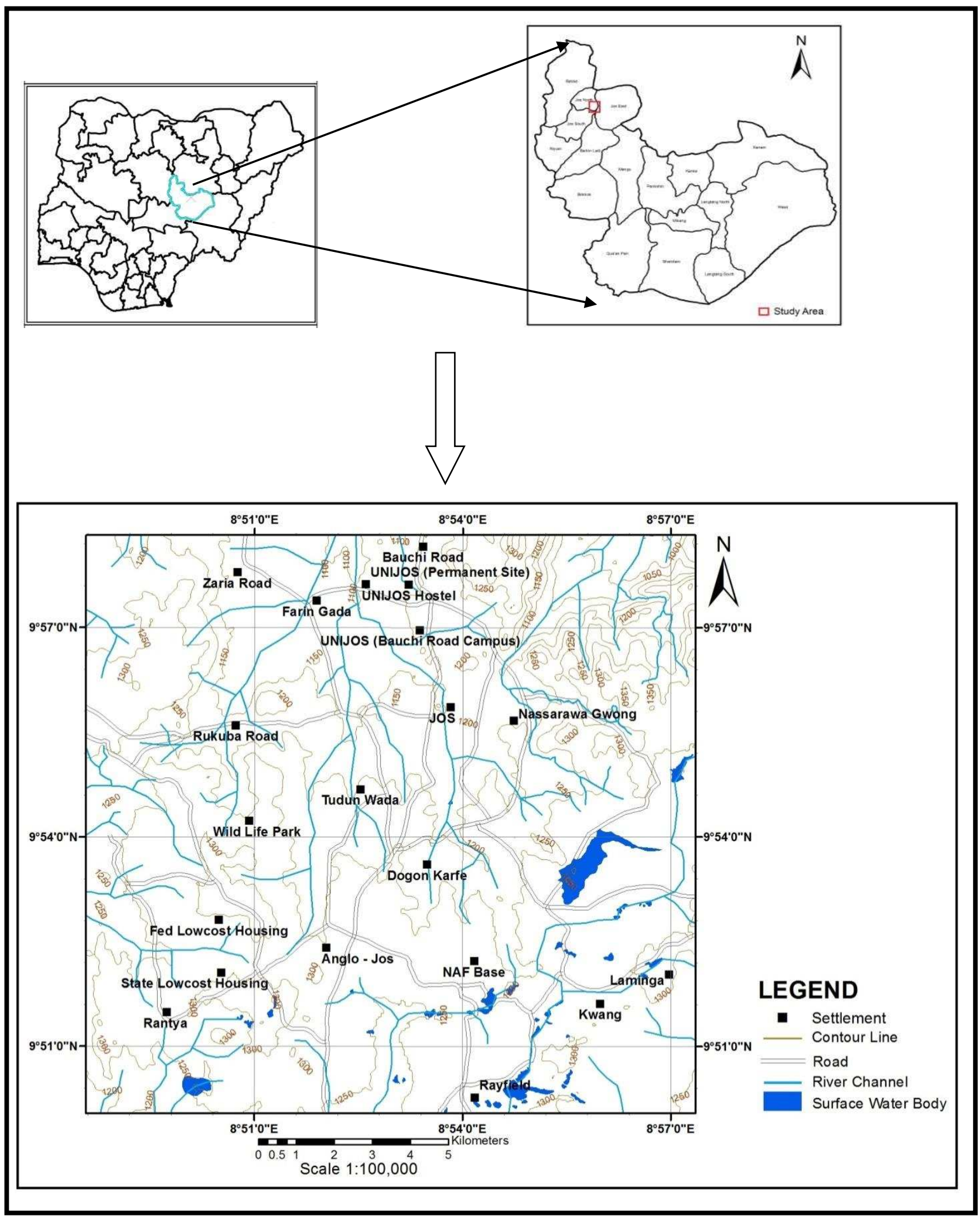

Figure 1: Location Map of the Study Area (Source: Authors) 


\section{MATERIAL AND METHODS}

\subsection{Data}

Five (5) data sets were used for this study:

1. NigeriaSat $-X$. (Source: NCRS Jos).

2. ASTER GDEM image ASTGTM_N09E009 of L2 processing level, acquired on 6/10/2003 from GLCF.

3. Geological map of Naraguta Sheet 168 1: 100,000 sereies (Source: Nigeria Geological Survey Agency).

4. Topographical map of Naraguta Sheet 168 NE, 1: 50,000 series produced and published by Federal Surveys Nigeria. (Source: NCRS Jos).

5. Borehole data

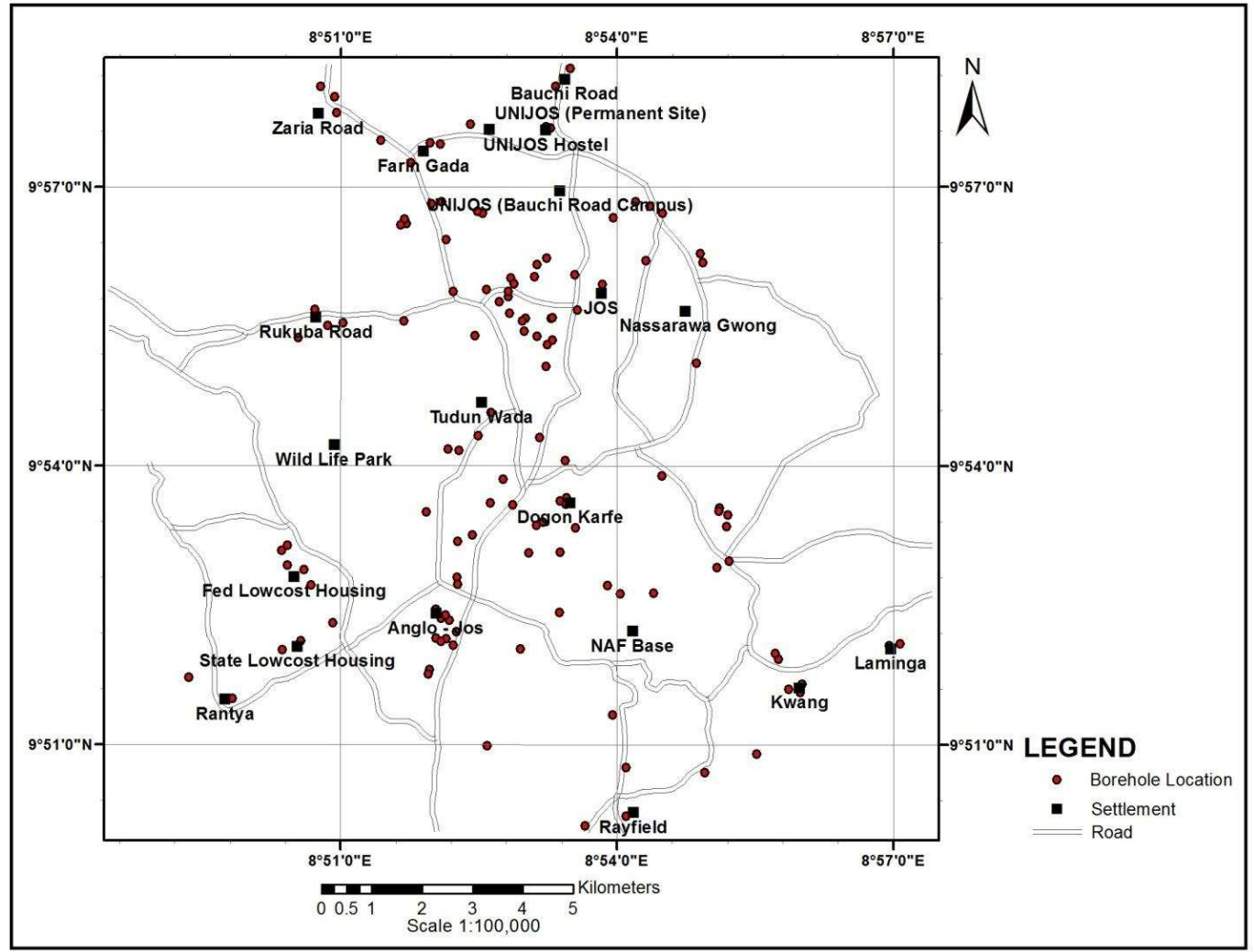

Figure 2: Borehole location map

\subsection{Method of study}

The topographic map Naraguta NE sheet 168 NE 1:50,000 series and geological map of the study area which was extracted from the Geological Survey of Nigeria 1: 100,000 series Naraguta sheet 168 were scanned and saved in TIFF format after which they were imported into ILWIS environment and 
subsequently georeferenced. Various layers were created from the georeferenced topographic and geological maps by on-screen digitization using ILWIS.

Digitizing is a process of converting an image into vector format. On screen digitizing was done in ArcGIS environment. Various layers of linear features; (roads and drainage), point features (settlement) and area features (lithological units, geomorphology and surface water bodies) were all digitized.

ILWIS software was used for digital image processing, while image enhancement including filtering and edge enhancement was carried out in order to improve the interpretability or perception of information in images for the viewer and also to provide better input for other automated image processing techniques. From the satellite images (Landsat ETM and ASTER - GDEM), the lineament and lineament density map, Geomorphology map and slope map were prepared using ILWIS 3.1 and Arc GIS 10.0.

Based on the Analytic Hierarchy Process (AHP) theory of measurement through pairwise comparisons, the different thematic layers; geology, geomorphology, surface water body, drainage, lineament and slope were assigned different weights according to their potential for groundwater. The Weighted Index Overlay Analysis (WIOA) was used to generate the Groundwater Potential Model of the study area. This was achieved by integrating all the thematic maps. This technique provides a method for combining multiple thematic maps by applying a common measurement scale of values to the layers, weighting each according to its importance, and adding them together to create an integrated map. In the present study the weighted overlay analysis has been carried out by giving weight to individual parameters as class weights and thematic maps as weighted theme, according to their degree of prospect for generating Groundwater Potential map. The sequential steps for this study have been summarized in Figure 3 below; 


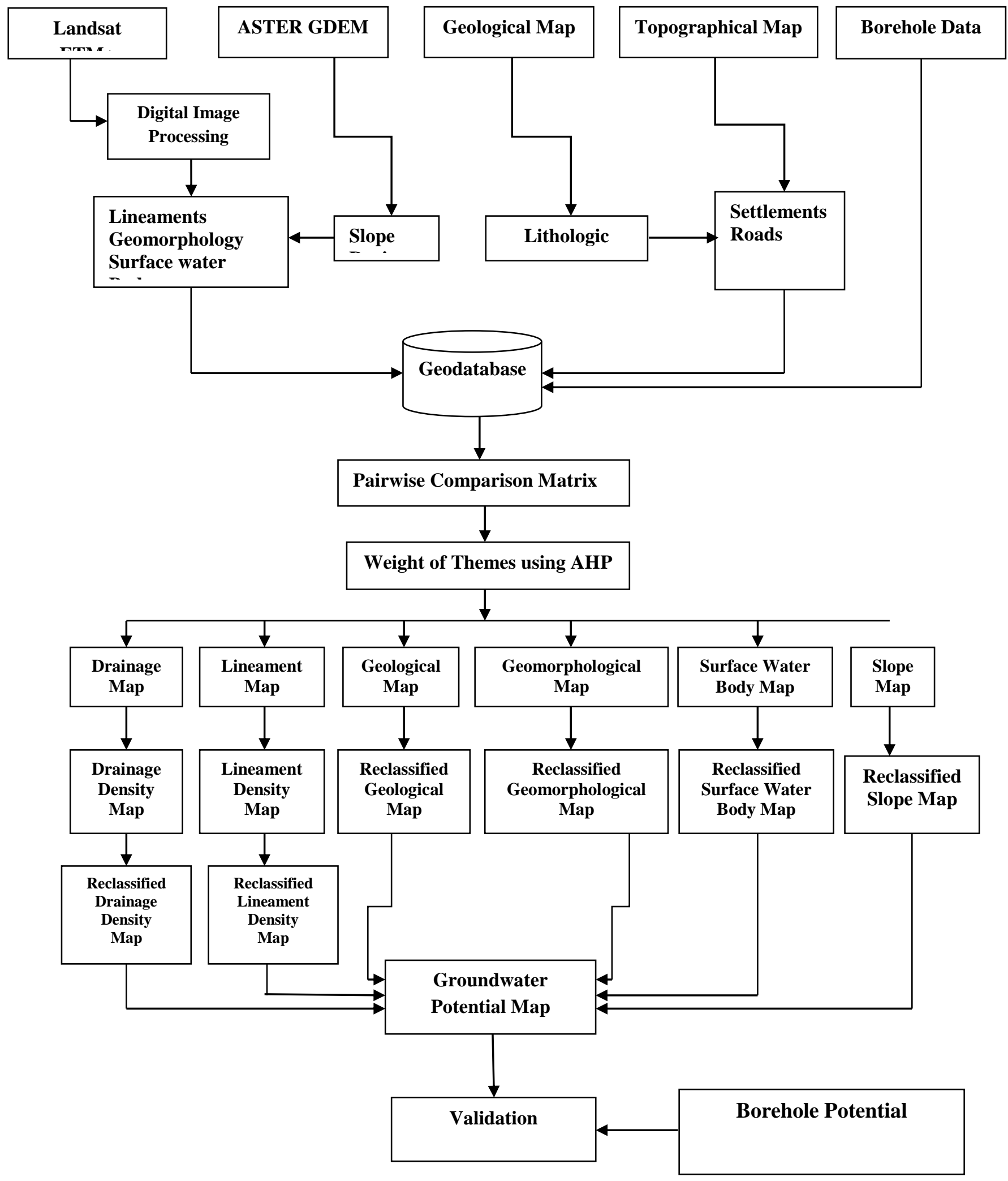

Figure 3: Work flow diagram for the study. 


\section{RESULTS AND DISCUSSION}

\subsection{Analytic Hierarchy Process (AHP)}

The different factors/ indicators were subjected to the pairwise comparisons matrix (Table 1) and subsequently the thematic weights were obtained (Table 2).

Table1: Pairwise Comparison Matrix.

\begin{tabular}{lccccccc}
\hline & $\begin{array}{l}\text { Lineament } \\
\text { Density }\end{array}$ & Geology & $\begin{array}{l}\text { Drainage } \\
\text { Density }\end{array}$ & Geomorphology & $\begin{array}{l}\text { Surface } \\
\text { Water } \\
\text { Body }\end{array}$ & Slope & $\begin{array}{l}\text { Eigen } \\
\text { Vector }\end{array}$ \\
\hline Lineament Density & 1 & 2 & 3 & 4 & 5 & 6 & 0.38 \\
Geology & 0.5 & 1 & 2 & 3 & 4 & 5 & 0.25 \\
Drainage density & 0.33 & 0.5 & 1 & 2 & 3 & 4 & 0.16 \\
Geomorphology & 0.25 & 0.33 & 0.5 & 1 & 2 & 3 & 0.11 \\
Surface water Body & 0.2 & 0.25 & 0.33 & 0.5 & 1 & 2 & 0.06 \\
Slope & 0.167 & 0.2 & 0.25 & 0.33 & 0.5 & 1 & 0.04 \\
\hline
\end{tabular}


Table 2: Thematic Weights and Ranking.

\begin{tabular}{|c|c|c|c|}
\hline Theme & Class & Rank & Weight (\%) \\
\hline \multirow{4}{*}{ Lineament Density } & High & 8 & \\
\hline & Medium & 6 & \\
\hline & Low & 4 & 38 \\
\hline & Very Low & 3 & \\
\hline \multirow{5}{*}{ Geology } & Laterite & 6 & \\
\hline & Microgranite & 3 & \\
\hline & Biotite - Granite Group & 4 & 25 \\
\hline & Rhyollite - Hornlende - & 7 & \\
\hline & Biotite Group & & \\
\hline \multirow{6}{*}{ Drainage Density } & Crystalline Basement & 9 & \\
\hline & Very High & 9 & \\
\hline & High & 7 & \\
\hline & Medium & 5 & 16 \\
\hline & Low & 3 & \\
\hline & Valley Fill & 9 & \\
\hline \multirow[t]{2}{*}{ Geomorphology } & Pediments/ Plain & 6 & 11 \\
\hline & Rock Outcrops/ Inselbergs & 2 & \\
\hline \multirow{3}{*}{ Surface Water Body } & $86.76-54824.50$ & 9 & \\
\hline & $54824.51-286913.28$ & 7 & 6 \\
\hline & $286913.28-1193228.65$ & 4 & \\
\hline \multirow{5}{*}{ Slope } & $0-2.87$ & 8 & \\
\hline & $2.87-6.03$ & 7 & \\
\hline & $6.03-11.01$ & 5 & 4 \\
\hline & $11.10-18.10$ & 4 & \\
\hline & $18.10-38.46$ & 2 & \\
\hline
\end{tabular}

\subsection{Lineaments}

Lineaments of the area were extracted from the Landsat ETM image of the study area (Figure 4). Lineaments provide important information on surface and subsurface features that may control the movement and or storage of groundwater.

Lineament density is the total length of all recorded lineaments divided by the area under consideration. The lineament density map for the area (Figure 5) was produced by interpolating the extracted lineaments using kernel density. Figure 6 was reclassified to produce the reclassified lineament density map of the study area. 


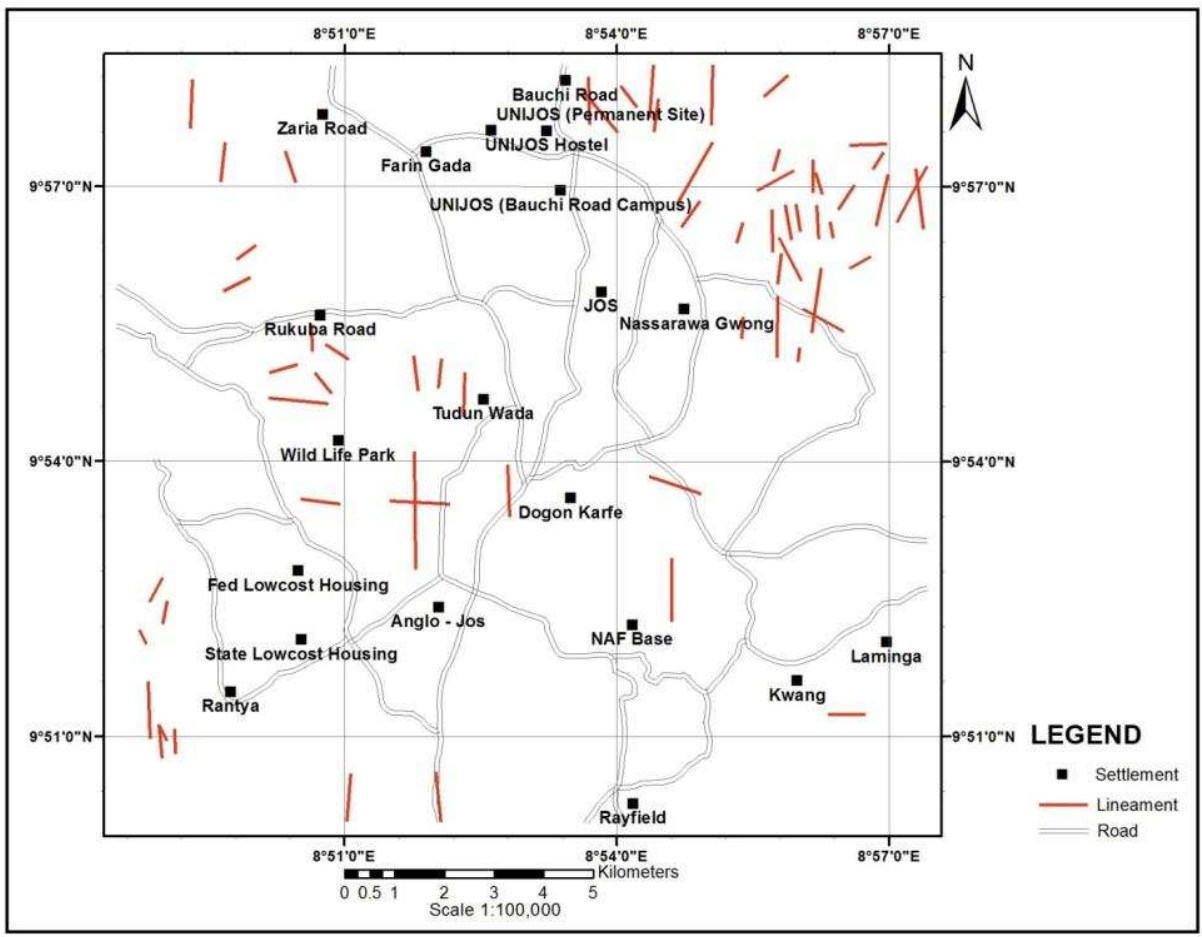

Figure 4: Lineament Map of the Study area.

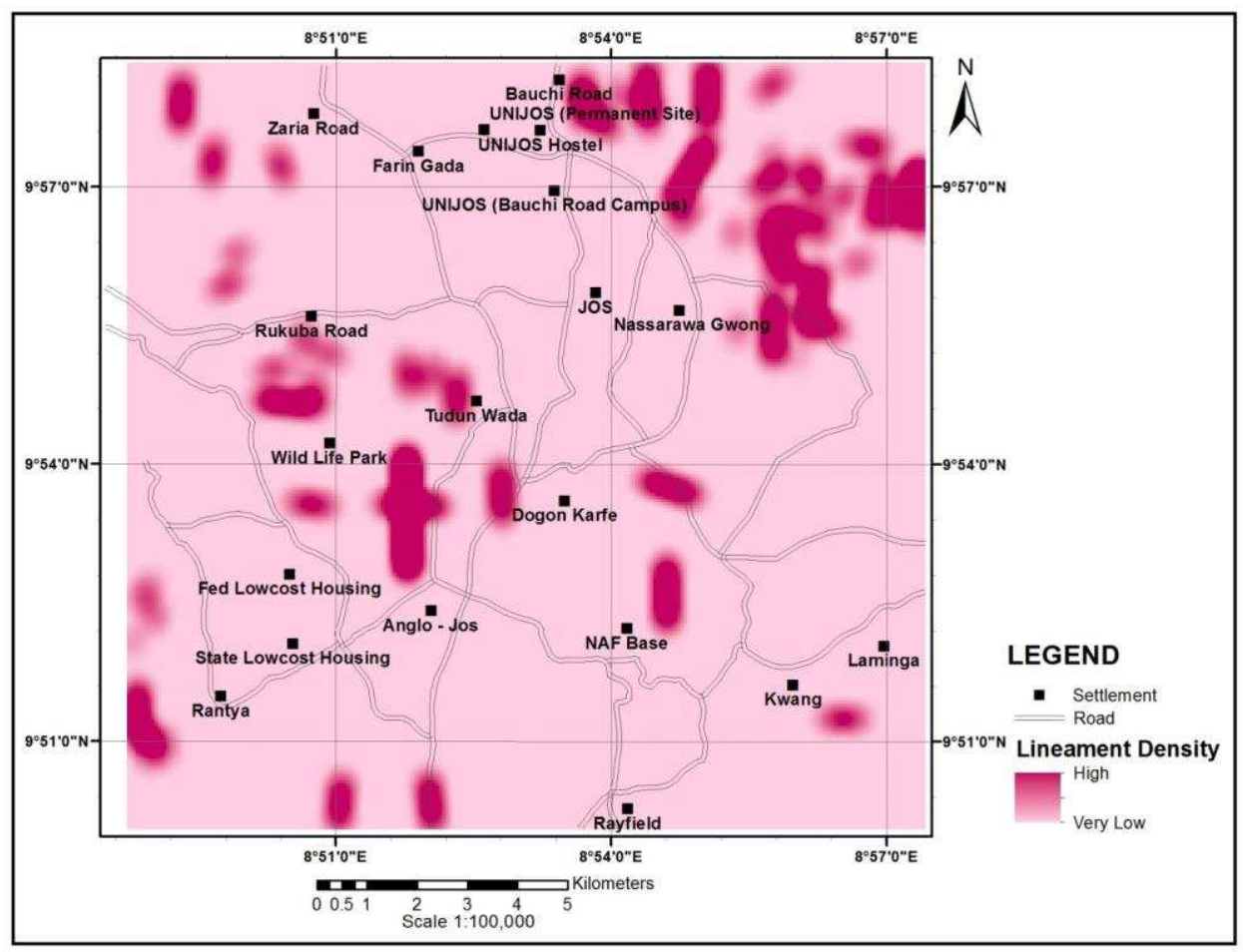

Figure 5: Lineament Density Map of the Study area. 


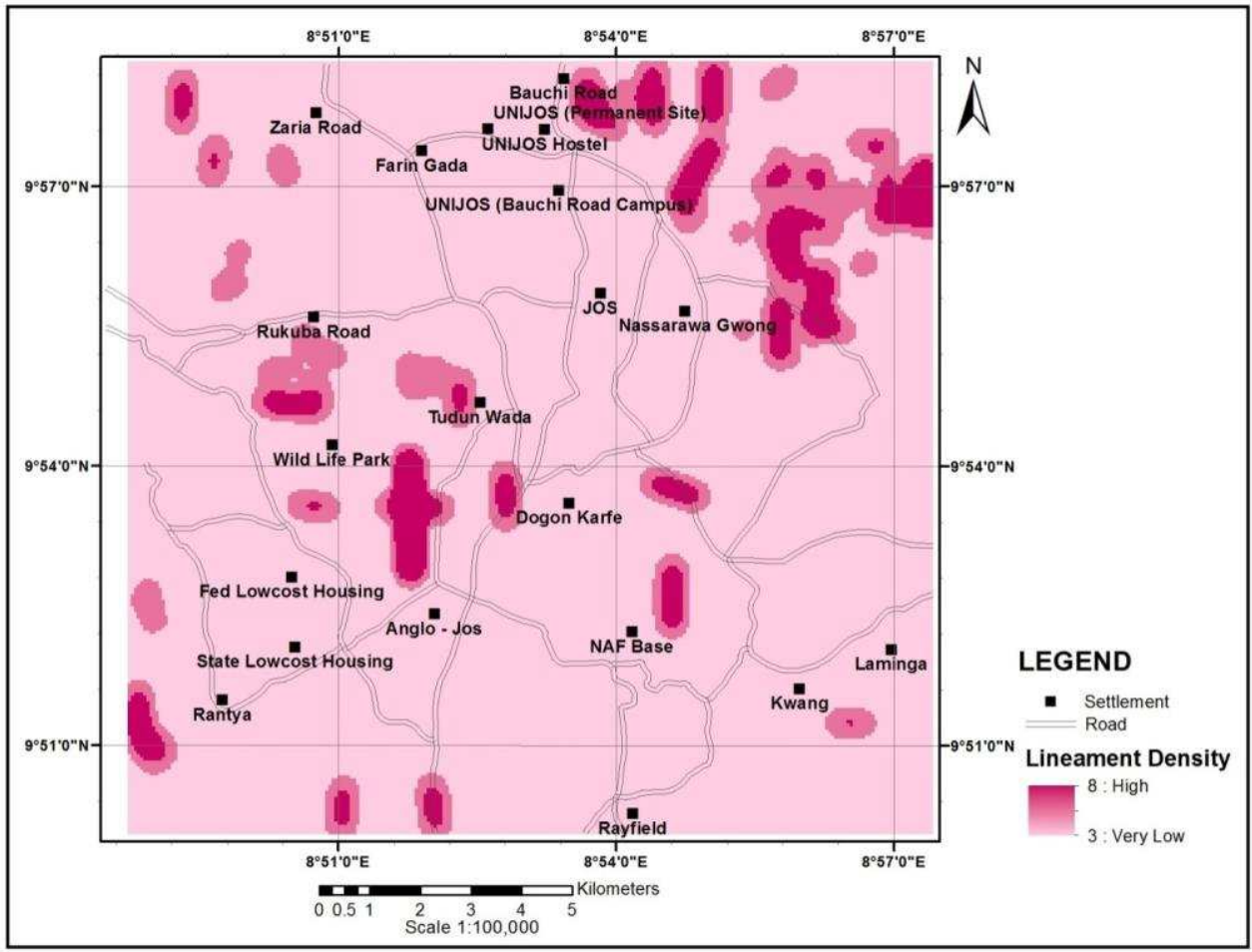

Figure 6: Reclassified Lineament Density Map of the Study area.

\subsection{Geology}

Geology is a major factor controlling the quality and quantity of groundwater occurrence in a given area, it is represented by the distribution of different rock units within the area. The geological map of the study area (Fig. 4.4) shows the different lithologic units within the area. Figure 6 shows the reclassified geological map of the study area.

\subsection{Groundwater Potential Model}

The Groundwater Potential Map of the study area (Figure 7) was produced by integrating the six thematic layers (drainage density, lineament density, geology, geomorphology, surface water body and slope) using Weighted Index Overlay Analysis (WIOA) in Arc GIS.

The groundwater potential zones have been categorized into five; Very high, high, moderate, low and very low 


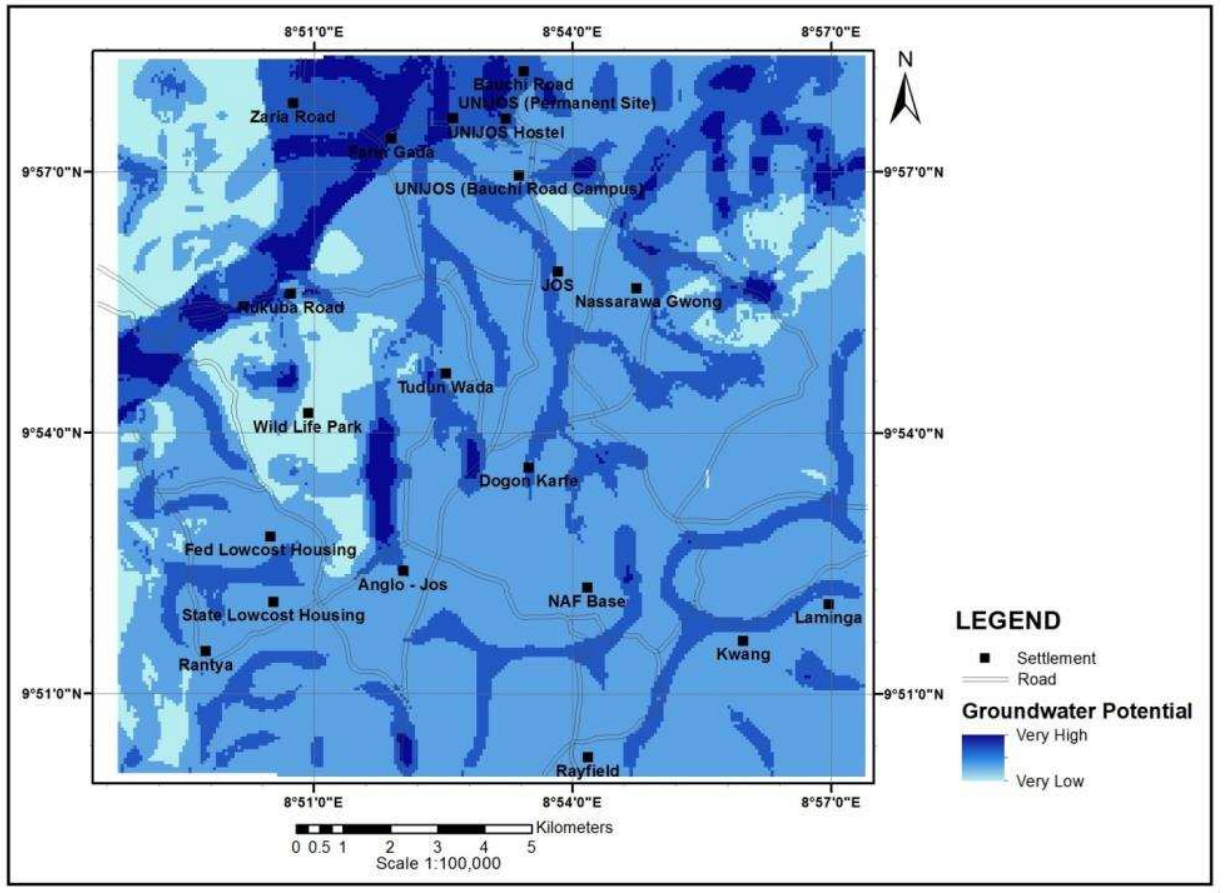

Figure 7: Groundwater Potential map of the study area

\subsection{Borehole potential}

From the borehole data the borehole potential was classified into; Very high, high, moderate, low and very low (Table 3).

In order to validate the classification of the groundwater potential zones as revealed by the integration of Remote sensing, GIS and AHP in this study, the groundwater potential model was validated using the Carruthers and Smith borehole yield template for groundwater prospect in Crystalline Basement terrains (Table 3).

The borehole data was superimposed on the groundwater potential map and the corresponding groundwater potential base on the model was evaluated (Table 3). The frequency distribution of various yields in different zones is presented in Figure 9. The percentage distribution of Borehole Potential within the study area is given in Figure 10. Out of the 127 boreholes within the study area, those with very high potential constitute $5 \%$ of the total and those with high potential cover $9 \% .62 \%$ of the boreholes are of moderate potential while $24 \%$ and $1 \%$ are of low and very low potentials respectively.

From result of the validation presented in Table 4.3 above.

Total number of boreholes within the study area $=127$

Number of boreholes where there is coincidence with groundwater potential model $=88$

Accuracy assessment $=\frac{88}{127} \times 100 \%$

$$
=69.29 \%
$$




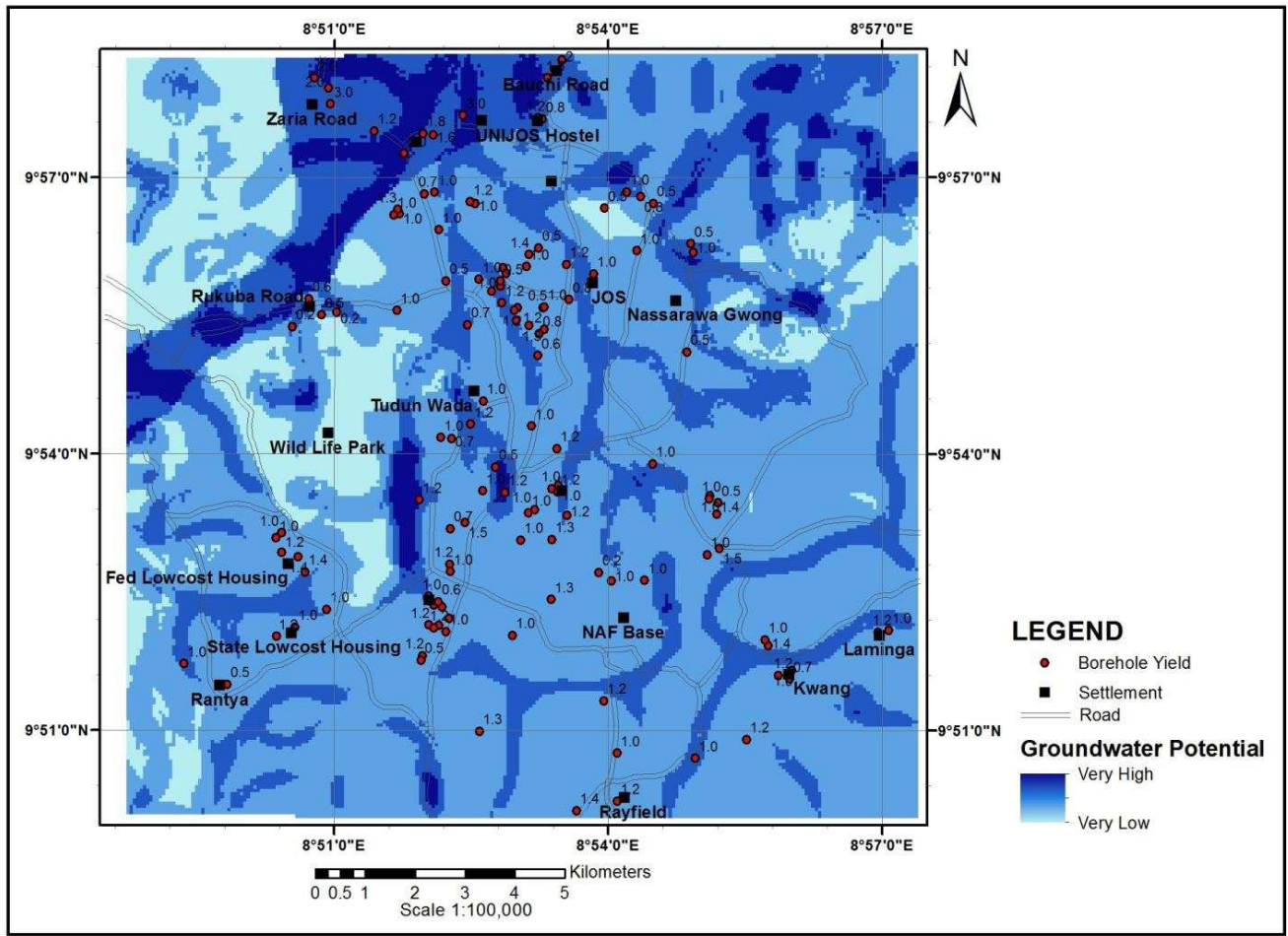

Figure 8: Correlation of boreholes and groundwater potential model.

Table 3: Statistical table of borehole potential within the study area.

\begin{tabular}{cccc}
\hline S/No & Groundwater Potential Interval (1/s) & Groundwater Potential & No. of Boreholes \\
\hline 1 & $>2.5$ & Very High & 2 \\
2 & $1.5-2.5$ & High & 8 \\
3 & $1.0-1.49$ & Moderate & 84 \\
4 & $0.5-0.99$ & Low & 28 \\
5 & $0-0.499$ & Very Low & 5 \\
\hline
\end{tabular}

L/s: Liters per second 


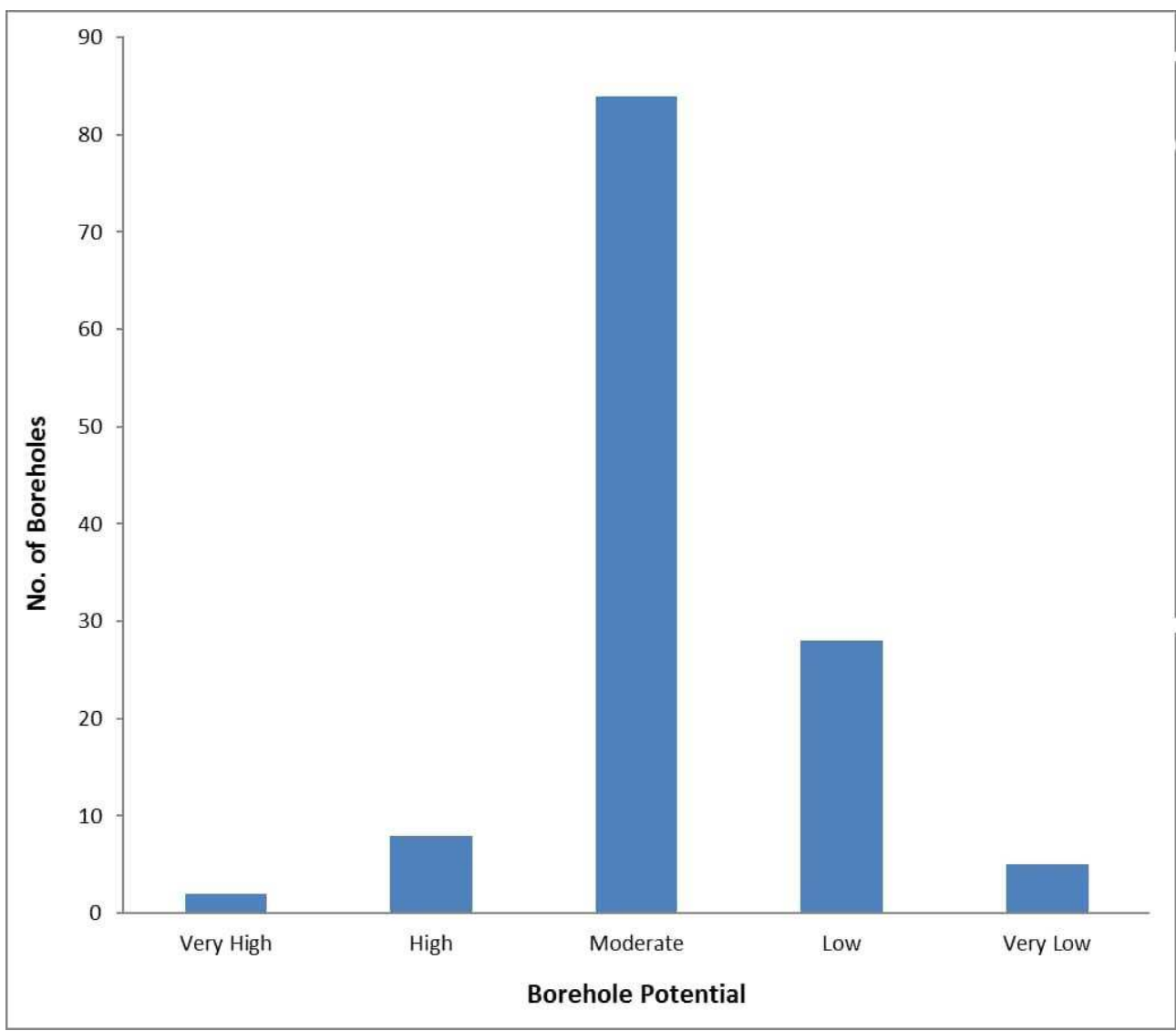

Figure 9: Frequency distribution of Borehole Potential within the study area.

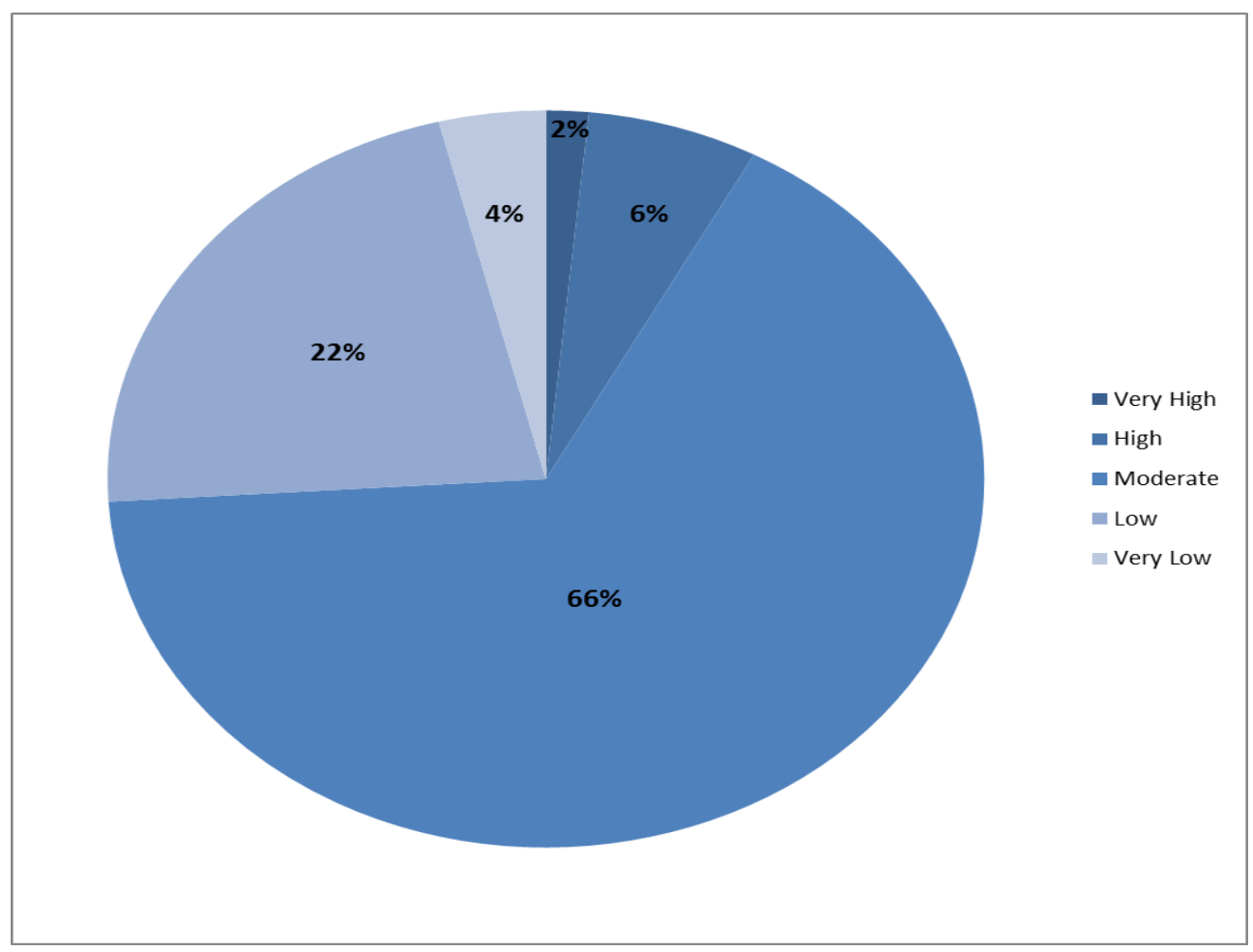

Figure 10: Percentage distribution of Borehole Potential within the study area.

The occurrence and movement of groundwater in an area is governed by several layers, such as topography, geology, geomorphology, structure, landuse, soil, rainfall, drainage density, groundwater 
depth and interrelationship between these layers (Jaiswal et al., 2003). Different thematic layers (lineaments, geology, drainage, geomorphology, surface water body and slope) were extracted and assigned weights using AHP MCDA method.

Lineaments provide important information on surface and subsurface features that may control the movement and or storage of groundwater. Lineaments are the manifestation of linear features that can play a major role in identifying suitable sites for groundwater recharge (Chowdaryet al., 2009). They are responsible for infiltration of surface runoff into subsurface and also for movement and storage of groundwater (Rao et al., 2001).

The lineament density of the study area was categorized into four; high, medium, low and very low. Areas with high lineament density are good for groundwater development (Sander, 2007). High values of lineament density are recorded in the northeastern part of the study area, while the northwestern and a portion in the southwestern have medium density. The central and southeastern parts have very low lineament density.

The study area comprises of the following geologic units; Crystalline Basement, Rhyollite - Hornlende - Biotite Group, Biotite - Granite Group, Microgranite and Laterite. Usually, massive unfracturedlithologic units in Basement Complex setting has little influence on groundwater availability except in cases with secondary porosity through the development of weathered overburden and fractured bedrock units, which form potential groundwater zones (Olutoyinet al., 2013). The zones underlain by the Crystalline Basement and Rhyollite - Hornlende - Biotite Group offers the best sites for borehole location while the areas underlain by Biotite - Granite and Microgranite are characterized by low borehole potential.

The drainage network of the project area is the dentritic type which is typical of basement terrains. Within the study area the river channels/ tributary are found in the Northwestern and northeastern parts, with few found in the southwestern and Southeastern parts. The drainage density which is expressed in terms of length of channels per unit area indicates an expression of the closeness of spacing of channels. It thus provides a quantitative measure of the average length of river channels within different portions of the whole study area.

The drainage density map is classified into five categories; very high, high, medium, low and very low. The area of very high drainage density represents more closeness of drainage channels and vice versa; hence, the higher the drainage density, the greater the runoff while the lesser the drainage density, the lower the runoff and the higher the probability of recharge or potential groundwater zone. It is well known that the denser the drainage network is, the less is the recharge rate and vice versa (Edetet al., 
1998). Within the study area, the northeastern and northwestern are characterized by high to very high drainage density, whereas the central and southeastern parts have very low drainage density.

In this study, three main geomorphological units were identified and delineated from the Landsat image of the study area, they are; rock outcrops/ inselbergs, pediments/ plains and valley fills. Rock outcrops/ inselbergs cover $77.23 \mathrm{~km}^{2}$, whereas pediments/ plains cover $150.47 \mathrm{~km}^{2}$ and Valley fill cover $14.69 \mathrm{~km}^{2}$ of the study area.

In groundwater exploration geomorphology plays an important role in identification of favorable zone for groundwater. More promising groundwater is in flood plains, alluvial fans and valley fills that are associated with thick alluvial and weathered materials to give high porosity and permeability. Pediments generally are not favorable for groundwater potential zones (Verstappen, 1983). Valley fill which constitute $12.70 \%$ is more favourable to groundwater potential than pediments/ plains and rock outcrops/ inselbergs which constitute $58.18 \%$ and $29.12 \%$ respectively of the study area.

On the basis of slope, the study area is divided into five slope classes; $0-2.87,2.87-6.03,6.03-$ $11.01,11.01-18.10$ and $18.10-38.46$. About $2 / 3$ of the area is under nearly level to gentle slope $(0-$ 2.87 and 2.87) category. Slope plays significant role in infiltration vs. runoff. Infiltration is inversely related to slope, i.e. more gentle the slope, infiltration would be more runoff would be less and vise versa. Low slope $(0-2.87$ and $2.87-6.03)$ indicate the presence of high groundwater potential zones, high slope $(18.10$ - 38.46) shows the presence of poor groundwater potential zones, as water runs rapidly off the surface. Therefore, groundwater potentiality is expected to be greater in the flat and gently sloping area (Solomon, 2003 and Subba, 2006).

The Groundwater Potential Map of the study area was produced by integrating six layers using the WIOA technique in ArcGIS. The groundwater potential of the study area is zoned into; very high, high, moderate, low and very low. The groundwater potential map revealed that some parts in the northwestern, parts of the northeastern and a portion in the extreme southwestern of the study area generally have very low potential. Low potential is seen in the extreme northwestern, some areas in the northeast and some southwestern parts of the study area. The north central, some northwestern and northeastern as well as southern parts generally exhibits moderate potential. The high and very high groundwater potentiality of the study area is restricted to some parts in the northwest, northeast and few places in the central and southwestern part of the study area. By superimposing the borehole yields on the groundwater potential model of the study area an assessment was carried out to ascertain the validity of the borehole potential within the study area, $69.29 \%$ of the boreholes were in coincidence with the groundwater potential model. 


\section{CONCLUSIONS}

The main objective of this study is to use remote sensing and GIS technique together with AHP MCDA to determine the groundwater potential of the study area. Hence, in this study, remote Sensing, GIS and AHP techniques have been successfully used to model the groundwater potential zones within the study area. Six factors; drainage, lineaments, geology, geormophology, surface water body and slope which play major roles in groundwater occurrence and movement were considered. Thematic maps were prepared and assigned weights using AHP technique. The groundwater potential map was produced using the WIOA tool in ArcGIS. The groundwater potential of the area is categorized into five; very high, high, moderate, low and very low. The groundwater model was compared and validated using borehole data obtained from different locations within the study area. The result showed a strong significant correlation between the model and the borehole potential. 


\section{REFERENCES}

Abubakar Y. I. and Auwal L. Y. (2012). Geoelectrical Investigation of Groundwater Potential of DawakinTofa Local Government Area of Kano State Nigeria.American International Journal of Contemporary Research Vol. 2 No. 9.

Adanu E. A. (1994). Groundwater Development and Management in the Basement Complex Terrain in Zaria, Kaduna Area. Water Resources 4(1 and 2): 64-68.

Amela C. K., Gunatilake J. and Dharmagunawardhane H.A. (2009). Groundwater Development in Hard Rocks - A GIS APPROACH. Journal of Geological Society of Sri Lanka Vol. 13 (2009), pp47-57.

Anudu G. K., Onuba L. N. and Ufondu L. S. (2011). Geoelectric sounding for groundwater exploration in the crystalline basement terrain around Onipe and adjoining areas, southwestern Nigeria. J. Appl. Technol. Environ. Sanit. 1(4):343-354.

Belton S. and Stewart T. S. (2002). Multiple Criteria Decision Analysis. An Integrated Approach. Kluwer Academic Publishers, Massachusetts.

Biswas A., Jana A. and Sharma S. P. (2012). Delineation of Groundwater Potential Zones using Satellite Remote Sensing and Geographic Information Techniques: A Case study from Ganjam district, Orissa, India. Research Journal of Recent Sciences, vol.1 (9), 2012, pp. 59-66.

Bowden P. and Turner D. C. (1973). Per Alkaline and Associated Ring Complexes in the Nigeria -Niger Province,West Africa'. In Soresen (Ed), Alkaline Rock, pp330 -351.

Chandra S., Rao V. A., Krishnamurthy N. S., Dutta S. and Ahmed S. (2006) Integrated studies for characterization of lineaments used to locate groundwater potential zones in a hard rock region of Karnataka, India. Hydrogeol. Jour., v.14, pp.1042-1051.Vijith, 2007.

Chowdhury, A., Jha, M.K., Chowdary, V.M. and Mal, B.C. (2009) Integrated remote sensing and GIS-based approach for assessing groundwater potential in West Medinipur district, West Bengal, India. Int. Jour. Remote Sensing, v.30, pp.231- 250 .

Edet A. E., Okereke C. S., Teme S. C. and Esu E. O. (1998). Application of remote sensing data groundwater exploration: A case study of the Cross River State, Southeastern Nigeria. Hydrogeology J. 6:394-404.

Grant N. K. (1969). The late Precambrian to early Palaeozoic pan African Orogeny in Ghana, Togo Dahomey and Nigeria GeolSocAme. Bull.80 p45-56.

Gupta R. P. (1991). Remote Sensing Geology, (Germany: Springer-Verlag), pp. 356.

Gupta M. and Srivastava P. K. (2010). Integrating GIS and remote sensing for identification of groundwater potential zones in the hilly terrain of Pavagarh, Gujarat, India. Water Int., v.35, pp.233-245.

Jaiswal R. K., Mukherjee S., Krishnamurthy J. and Saxena R., (2003). Role of remote sensing and GIS techniques for generation of groundwater prospect zones towards rural development-an approach. Int J Remote Sens 24:993-1008.

Jha M., Chowdhury A., Chowdary V. and Peiffer, S. (2007) Groundwater management and development by integrated remote sensing and geographic information systems: prospects and constraints. Water Resource Management 21(2), 427-467.

Krishnamurthy J., Mani A.N., Jayaram V. and Manivel M. (2000). Groundwater resources development in hard rock terrain: An approach using remote sensing and GIS techniques. Int. Jour. Appld Earth Obser. Geoinformatics, v.2, pp.204215.

Macleod W. N., Turner D. C and Wright E. P. (1971). The Geology of Jos Plateau. Geol. Sun-Nigeria, Bull. No. 32. Vol. 2. $\operatorname{Pg} 160$.

Manimaran D., (2012). Groundwater geochemistry study using GIS in and around Vallanadu Hills, Tamilnadu, India, Res. J. recent sci, 1(6), 32-37.

Mbilmbe E. Y., Samaila N. K. and Akanni D. K. (2010). Groundwater Exploration in a Basement Complex terrain using electrical Resistivity Sounding (VES): a case study of RiminGado town and Environs, Kano State North Central Nigeria. Continental Journal Earth Sciences, 5 (1), 56-63. 
Meijerink A. M. J. (1996). Remote sensing applications to hydrology: groundwater. HydrolSci J 41(4):549-561.

McCurry P. (1973). Geology of Degree Sheet 21, Zaria Nigeria Overseas Geol Mineral Resource London 45p.

McCurry P. 1976. The Geology of the Precambrian to Lower Palaezoic rocks of Nothern Nigeria, a review in Geology of Nigeria, edited by C.A. Kogbe, pp: 15-39, Elizabelthan Pub. Co. Lagos.

Mogaji K. A., Omosuyi G. O. and Olayanju G. M. (2011). Groundwater system evaluation and protective capacity of overburden material at Ile-olujI, Southwestern Nigeria Journal of Geology and Mining Research Vol. 3(11) pp. 294304.

Murthy K. S. R. and Mamob A. G. (2009). Multi-criteria decision evaluation in groundwater zones identification in MoyaleTeltelesubbasin, South Ethiopia. Int. Jour. Remote Sensing, v.30, pp.2729-2740.

Olorunfemi M. O., Ojo J. S. and Akintunde O. M. (1999). "Hydrogeophysical Evaluation of the Groundwater Potential of Akure Metropolis, South-Western Nigeria”. Journal of Mining and Geology. 35(2):207 - 228.

Olutoyin A. F., Tijani M. N., Abel O. T. and Oluwatola I. A. (2013). Delineation of groundwater potential zones in the crystalline basement terrain of SW-Nigeria: an integrated GIS and remote sensing approach. Appl Water Sci DOI 10.1007/s13201-013-0127-9.

Omeje M., Husin W., Noorddin I., Oha I. A., Onwuka O. S., Ugwuoke P. E. and Meludu O. (2013). Geoelectrical investigation of aquifer problems in Gosa area of Abuja, North Central, Nigeria. Academic Journals Vol. 8(13), pp. $549-559$.

Onugba A. and Eduvie O. M., "Hydrogeology of Nigeria. Paper on Groundwater Workshop," Organized by United Nations Children's Fund, Jos, 2003, p. 20.

Phukan I., Ravindran K.V. and Banerjee D.M., (1999). Delineation of Groundwater Prospect Zones using Remote Sensing and Geographic Information System in the West Garo Hills District, Meghalaya, "Geoinformatics: Beyond 2000", an International Conference on Geoinformatics for Natural Resource Assessment, Monitoring and Management, Jointly Organized by Indian Institute of Remote Sensing (National Remote Sensing Agency) Dehradun, India and ITC (International Institute for Aerospace Survey and Earth Sciences) The Netherlands, 203-211 (1999).

Rahaman M. A. (1976). Review of Basement of southwestern Nigeria. In: Kogbe, C. (Ed.), Geology of Nigeria, Elizabethan Press, Lagos. P41-58.

Ravindran A. A. (2012). Azimuthal Square Array Resistivity Method and Groundwater Exploration in Sanganoor, Coimbatore District, Tamilnadu, India, Res. J. recent sci, 1(4), 41-45.

Samaila C. A. and Solomon N. Y. (2011). Groundwater Potential on the Jos-Bukuru Plateau, Northcentral Nigeria Using Lineaments from Gravity Measurements. Journal of Water Resource and Protection, 628-633.

Sander P. (2007). Lineaments in groundwater exploration: A review of applications and limitations. Hydrogeol. J., 15 : 71 -74.

Saaty T. L. 1994b. Fundamentals of Decision Making, RWS Publications, Pittsburgh, PA.

Schowengerdt R. A. (2007). Remote sensing: models and methods for image processing (3rd ed.). Academic Press. p. 2.ISBN 978-0-12-369407-2.

Subba Rao N., Chakradhar G. K. J. \& Srinivas, V. (2001) Identification of groundwater potential zones using remote sensing techniques in and around Gunur town, Andhra Pradesh, India. J.IndianSocRemoteSens, 29, 69-78.

Suja Rose, R.S. and Krishnan, N. (2009) Spatial analysis of groundwater potential using remote sensing and GIS in the Kanyakumari and Nambiyar basins, India. Jour. Indian Soc.Remote Sensing, v.37, pp.681-692.

Srivastav P. and Bhattacharya A. K., (2000). Delineation of groundwater potential zones in hard rock terrain of Bargarh District, Orissa using IRS, Jour. India. Soc. Rem. Sen, 28(2-3), 129-140.

Todd D. K. and Mays L. W. (2005). Groundwater Hydrology. 3rd edition, John Wiley \& Sons, NJ,pp. 636.

Turner D. C. (1983). Upper Proterozoic Schist Belts in the Nigeria Province of West Africa,

Precambrian Res. 21 p 55-59. 
Verstappen H. T. (1983). Applied Geomorphology, Geomorphologic Survey for Environmental Development, International Institute for Aerial Survey and Earth Science (I.T.C.) Enschede, the Netherlands, pp434.

Vijith H. (2007). Groundwater potential in the hard rock terrain of Western Ghats: a case study from Kottayam district, Kerala using Resourcesat (IRS-P6) data and GIS techniques. Jour. Indian Soc. Remote Sensing, v.35, pp.163-171. 